\title{
Higher Education Goals and University Ranking: Random Variables?
}

\author{
Olga R. Bondarenko ${ }^{1}$ \\ ${ }^{1}$ Historical and Archival Institute, Russian State University for the Humanities, Moscow, Russia \\ Correspondence: Olga R. Bondarenko, Historical and Archival Institute, Russian State University for the \\ Humanities, 6 Miusskaya Pl., Moscow, 125047, GSP-3, Russia. E-mail: orbon@mail.ru
}

Received: January 23, 2022

Accepted: February 18, 2022

Online Published: February 21, 2022

doi:10.20849/jed.v6i1.978

URL: https://doi.org/10.20849/jed.v6i1.978

\begin{abstract}
University mission determination is involved in higher education outcomes. Although educational goals are a backbone construct for any higher education institution, they are seldom addressed, underestimated, and are hardly considered for calibration in university ratings. The purpose of this exploratory study was to scrutinize universities' strategic missions and trace any coincidences between them and the university's academic success materialized as QS rank. Relying on the framework of a descriptive research the author applied the techniques of coding, thematic analysis, comparison, and interpretation. The main findings show that top group universities' goals representing the liberal values are more focused on individual success and global pursuits than the goals of non-top universities considered. Educational goals of non-top universities are locally marked and have specifics of their own. Hence, strategic goals of universities across the globe may not necessarily coincide with the Anglo-Saxon core values that underpin the QS global university ranking system.
\end{abstract}

Keywords: educational goals, higher education missions, educational values, universities ranking, QS world university ranking

\section{Introduction}

The sphere of higher education is most vital both for society and an individual. The quality performance of higher learning institutions depends on various factors, one of them being strategic educational purposes or missions, which shape the university development direction, educational policies, distal and proximal tasks. Despite the evident strategic significance of higher education goals (EGs) for civilized community in general and for academia in particular, scholarly research does not answer the question, what goals higher education actually pursues today (Wawrzinek et al., 2017, p. 15). Meanwhile, these purposes may be worlds apart: for instance, just to teach future workers or to help students reach their individual human potential (Meredith, 2014). So, what is the mission of higher education?

Higher education goals can be conceived and perceived from various perspectives. According to the authors of the goal-setting theory, setting a goal is a key motivational process because, developing a vision for the whole organization as a distal goal excites people into action by giving them an objective (Latham \& Locke, 1991, p.240). Goals are essential for increasing student achievement and motivation (Ambrose et al., 2010). Conceptualized through achievement goal theory, classroom contexts are proved to affect student participation (Anderman \& Patrick, 2012). According to the achievement goal theory, students' motivation is influenced not only by their individual personal characteristics, world views, and achievements, but also by the social contexts in which they learn. Within these environments, what constitutes achievement and success influences their goal orientations and therefore plays a significant role in affecting the nature and quality of engagement in learning tasks (Nicholls et al., 1989). Moreover, not only students, but also employees of educational institutions are under the influence of general strategic goals. Studies in the educational environment found that performance-prove goals can influence significantly institutional culture through the motivation of employees (Dietz et al., 2015). Besides, EGs perform a backbone function in pedagogical activity as they guide practical instructors in various aspects of teaching, as they determine pedagogical means and ways, content, methods, activities and tools selection. A shift in general education goals entails a shift in particular tasks, for instance, a shift from imparting an established body of knowledge to preparing for life-long learning unequivocally leads to developing pedagogies to promote learning skills especially (Cervone \& Cushman, 2012).

Whereas students' expectations and goals are considered rather personal and instrumental (Chan, Brown, \& 
Ludlow, 2014, p. 11), higher education institutions' objectives are much larger, more grandiose and are to do with "reforming society and the classic individual cognitive and communicative agendas" in the USA, for example (Chan, Brown and Ludlow, 2014, p. 9). To attain higher education societal goals, universities must apply strategies with goals that can be measured (Wawrzinek et al., 2017, p.17). But there is more to it. As concepts of higher education quality vary between countries and regions (de Wit \& Hunter, 2017), these differences cannot but be taken into account when evaluating the work of universities.

Higher education goals undergo changes during time. Thus, under the influence of globalization higher education is getting commercialized today turning into a commodity of knowledge-based products for the market (Bagley \& Portnoi, 2014). Some scholars see in higher education an instrument for nations to improve foremost the economic conditions for citizens (Lemoine et al., 2017). Contrary to this viewpoint, others claim that education is being valued as more than a simple commodity but as a public good (Mense et al., 2018), producing noticeable benefits not only to individuals but also to the whole society (Kauppinen, 2014). In other words, strategic EGs are very significant for leveraging or impeding further national, university, or personality progress and can ensure or interrupt social-humanitarian continuity. Interestingly, while higher education is increasingly viewed as a major instrument to maximize global effectiveness, at the same time it is marked as essential for higher education institutions to retain a strong sense of identity and purpose (Stensaker et al., 2019), which spells more freedom of action including goal-setting.

Recognizing the existing dichotomy between "what is effective" and "what is important in learning," - Peterson considers it possible to resolve it with the help of adopting a particular education mission (Peterson et al., 2018). As justly emphasized by the scholars, efficiency is unattainable without educators' awareness and conceptualization of their mission, which leads to necessity to focus on intentions when evaluating pedagogies rather than assume that all have the same purpose (Peterson et al, 2018, 4). Noting the fundamental importance of purpose, Peterson distinguishes between two layers in pedagogies: not only discrete teaching practices but meeting long-term educational goals. Specifying these long-term goals some scholars believe that the quality of education is measured by the quality of the person produced by it. Emphasizing the necessity to harmoniously combine European integration and sustainable development with national identity (Бондаревская, 2013, 5), the Russian educationist Bondarevskaya asserts that the priority focus of education is on the holistic development of the personality primarily as a subject of native culture (Бондаревская, 2010, p. 45, 50).

In other words, strategic EGs reveal various perspectives and foci cross-culturally and cross-ideologically. They anchor learning and teaching processes and are of top priority for efficient results of university operation. And, as researchers affirm, quality assurance in global higher education has become top priority on the higher education policy agenda (Waller et al., 2020).

Although it is evident that the performance results of a higher educational institution, among other things, are related to its goals, the theme of strategic educational goals of universities is not much addressed, nor treated with unanimity by the academia (Schwartz, 2013). In reality, this issue is civilization significant, crucial for cultural diversity protection and visible educational results. Just as corporate success depends on staff's awareness and sharing the company's mission, university operation results are probably related to strategically set and achieved goals.

An overview of research literature, academic conference proceedings, and university ranking metrics show that strategic EGs are seldom addressed by researchers and do not seem to be considered for assessing university efficacy. Although higher education goals determination is a systemic issue crucial for successful university activity, it is inadequately highlighted in academic research, and relationship between EGs and university performance results is not much investigated. It is customary today to rate higher educational institutions on the basis of supposed plausible metrics of established ranking centers. But do they consider universities' missions and strategic goals? Are EGs of universities aligned with the standards of the ranking system? If the measure yardsticks do not quite correspond to the education mission of a university the latter may stay on the margins of the ranking system a-priory.

Relying on the findings of the previous researchers this paper seeks to contribute to existing knowledge by highlighting the importance and diversity of national strategic long-term goals of higher education and by collating them and international evaluating criteria for universities. The paper claims that objective assessment of a university's operation is hardly possible outside the socio-cultural context and without considering university EGs, which vary across countries and cultures and cannot but be taken into account when evaluating the work of universities. 


\section{Purpose of the Study}

This study aimed to scrutinize universities' strategic missions and trace any coincidences between them and the universities' QS ranks.

The hypothesis of this study was educational goals of world universities may have relationship with their rankings, i.e. world universities' differing rankings may signal preexisting differences in their educational goals. In other words, there may be implicit relationship between the strategic goals of a university and its world status manifested by its QS rank.

The problem questions developed are the following: Is there any relationship between the university rank and its declared educational goals and values? Are there EGs and values characteristic of cohorts of universities of similar ranks? If there are any locally-colored EGs, what QS ranks do they relate to? Are internationalized educational metrics aligned with local EGs? Are universities' goals and university world ranks just random variables?

\section{Methods and Procedures}

The object of this exploratory study was shared EGs of 21 randomly selected universities conventionally representing three groups of universities in the QS Yearbook (QS World University Rankings Yearbook, 2021). The Quacquarelli Symonds ranking was chosen as one of the most-widely read world university rankings that had received approval from the International Ranking Expert Group (IREG). The universities selected for this research represented all the continents and included Anglophone, Arab, French, Jewish, Chinese, Japanese, South-Eastern, West-European and Russian higher educational institutions. Three cohorts of universities were represented: 7 universities in the top hundred, 7 in the medium 2-3rd hundreds, and 7 in the 9-12th peripheral hundreds according to the QS ranking. Division into the cohorts was merely conventional and was made for the convenience of analysis. Some universities initially chosen for the study were later declined for scarce or unavailable information concerning their strategic goals and mission. Selecting representatives of the 3 groups was relatively randomized but guided by geographical and cultural diversity principle: universities represented various continents and cultures. They are the following:

The first cohort: Stanford University ( $\mathrm{QS}=2)$, University of Oxford ( $\mathrm{QS}=5)$, Peking University (QS=23), the University of Tokyo ( $\mathrm{QS}=24)$, Lomonosov Moscow State University ( $\mathrm{QS}=74)$, University of Toronto ( $\mathrm{QS}=82$ ), Sorbonne University (QS=83);

The medium cohort: King Abdul Aziz University, Saudi Arabia (QS=143), Indian Institute of Technology, Bombay (QS=172), Hebrew University of Jerusalem (QS=177), Chulalongkorn University, Thailand (QS=208), St.-Petersburg State University, Russia ( $Q S=225)$, Novosibirsk State University, Russia ( $Q S=228)$, Higher School of Economics, Russia (QS=296).

The peripheral cohort: University Tunku Abdul Rahman, Malaysia (QS=801-1000), University of Brasilia (QS=801-1000), Alexandria University, Egypt (QS=801-1000), University of Latvia (QS=801-1000), Shiraz University of Medical Sciences, Iran (QS=801-1000), Russian State University for the Humanities (QS=1001-1200), Diponegoro University, Indonesia (QS=1001-1200).

The methods used included literature review, an online public documentary study of world university missions, thematic analysis, comparison and interpretation. Thematic qualitative data analysis (Auerbach \& Silverstein, 2003) based on extended phrases and/or sentences was carried out. Relying on the framework of a thematic analysis the technique of inductive coding was applied. The data about strategic EGs and values of universities were gathered from the open Internet resources including the Vision and Mission part of the Universities' Charters, Development programs and other fundamental documents. Only goals, mentioned by two or more universities of the same cohort were taken into account. In this way strategic EGs of the universities considered were determined. Then, data coding procedures were applied: the goals were generalized, categorized, and regrouped so that differently worded but semantically similar propositions were reduced to the same formulation; then themes were developed. Since the scale of this study was limited manual coding was applied instead of Thematic AI tool. The data collector, the author, was the same throughout the research.

\section{Results}

The research results are presented in Table 1 . 
Table 1. Educational goals dominant in three groups of the QS 2021 university ranking

\begin{tabular}{|c|c|c|}
\hline Top hundred universities & $\begin{array}{c}\text { Medium }\left(2^{\text {nd }}, 3^{\text {rd }} \text { hundreds }\right) \\
\text { universities }\end{array}$ & $\begin{array}{l}\text { Peripheral }\left(9^{\text {th }}-12^{\text {th }} \text { hundreds }\right) \\
\text { universities }\end{array}$ \\
\hline $\begin{array}{l}\text { Promoting excellence (Stanford } \\
\text { University, USA; Oxford } \\
\text { University, UK; University of } \\
\text { Toronto, Australian National } \\
\text { University, Peking University, } \\
\text { Sorbonne) }\end{array}$ & $\begin{array}{l}\text { Promoting excellence (King Saud } \\
\text { bin Abdulaziz University, SA; } \\
\text { Hebrew University, Israel; } \\
\text { Chulalongkorn University, } \\
\text { Thailand) }\end{array}$ & $\begin{array}{l}\text { Promoting excellence (Alexandria } \\
\text { University, Egypt; University of } \\
\text { Latvia; Shiraz University of } \\
\text { Medical Sciences, Iran; University } \\
\text { Tunku Abdul Rahman, Malaysia; } \\
\text { University of Brasilia) }\end{array}$ \\
\hline $\begin{array}{l}\text { Provision of fundamental education } \\
\text { (Stanford; University of Toronto; } \\
\text { Lomonosov University, Russia) }\end{array}$ & $\begin{array}{l}\text { Provision of fundamental education } \\
\text { (Novosibirsk University, Russia) }\end{array}$ & $\begin{array}{l}\text { Provision of fundamental education } \\
\text { (Russian State University for the } \\
\text { Humanities) }\end{array}$ \\
\hline
\end{tabular}

Preparing for future challenges

(Oxford; Peking University;

Lomonosov University)

Preparing personal success, developing leadership qualities (Stanford, Oxford, Australian National University, Tokyo University)

Contributing to real world problems solution (Stanford, Oxford, Peking University, Sorbonne)

Contributing to bettering native community, region or country (Stanford, Oxford, Australian National University, Peking University, Tokyo University, Lomonosov University)

Impacting the world through cultural, societal, political and economic change (Stanford, Oxford, Sorbonne, Peking University).

Developing inventiveness, creativity (Peking University, Tokyo University)

Preparing personal success, developing leadership qualities (King Abdulaziz University, Indian Institute of Technology Bombay; Hebrew University, Chulalongkorn University)

Contributing to real world problems solution (Indian Institute of Technology, Bombay;

St.-Petersburg University, Russia)

Providing understanding of local society needs (Novosibirsk University, Indian Institute of Technology)

Contributing to bettering native community, region or country (Hebrew University, Indian Institute of Technology,

St.-Petersburg University, Novosibirsk University, Higher School of Economics, Russia)

Impacting the world through cultural, societal, political and economic change (Higher School of Economics)

Developing inventiveness, creativity (King Abdulaziz University, Hebrew University, Indian Institute of Technology Bombay, Chulalongkorn University)

Integrating into the world labor market (St.-Petersburg University, Higher School of Economics) Inculcating freedom (Hebrew
Preparing personal success, developing leadership qualities (Universiti Tunku Abdul Rahman, Alexandria University; University of Latvia)

Contributing to real world problems solution (University Tunku Abdul Rahman)

Providing understanding of local society needs (Alexandria University, Voronezh University, Russia)

Contributing to bettering native community, region or country (Universiti Tunku Abdul Rahman; Alexandria University; Diponegoro University, Indonesia; Shiraz University)

Developing inventiveness, creativity (Universiti Tunku Abdul Rahman, Alexandria University, University of Latvia, Voronezh University)

Integrating into the world labor market (University of Latvia, Diponegoro University, University of Brasilia)

Inculcating freedom (Alexandria 
Oxford, Peking University, Tokyo University)

Preserving cultural and national foundations (Peking University, Lomonosov University)

Fostering commitment to sustainable development (Lomonosov University)

Inculcating social responsibility (Tokyo University, Sorbonne)

Cultivating ethics and morality (Lomonosov University)

\section{University, Higher School of Economics)}

Preserving cultural and national foundations (Hebrew University, St.-Petersburg University, Novosibirsk University)

Integrating into the national job market (Hebrew University, St.-Petersburg University)

Fostering commitment to sustainable development (St.-Petersburg University)

Inculcating social responsibility (King Abdulaziz University, Chulalongkorn University, Higher School of Economics)

Cultivating ethics and morality (Novosibirsk University)

Developing individual abilities (Novosibirsk University)

Inculcating life-long learning (Novosibirsk University)
University, University of Brasilia)

Preserving cultural and national foundations (Diponegoro University, University of Latvia, Shiraz University)

Fostering commitment to sustainable development (Diponegoro University, University of Brasilia, Alexandria University)

Inculcating social responsibility (Universiti Tunku Abdul Rahman, Alexandria University, Shiraz University, University of Brasilia)

Cultivating ethics and morality (University of Brasilia, Universiti Tunku Abdul Rahman, Diponegoro University, Alexandria University, Shiraz University)

Developing individual abilities (Russian State University for the Humanities, Alexandria University, Universiti Tunku Abdul Rahman, University of Latvia).

Inculcating life-long learning (Universiti Tunku Abdul Rahman, Alexandria University, Russian State University for the Humanities, Diponegoro University).

The main findings show that each of the three cohorts of universities has a core of similar repeated EGs. Core goals differ across the 3 groups of universities in thematic dominants revealing some trends: (a) Certain goals are markers of the top universities (e.g. preparing personal success; inculcating freedom; impacting the world through cultural, societal, political and economic change); top universities' goals representing the liberal goals of education are more openly focused on individual success and serving global pursuits than the goals of the other two groups; (b) although many of the top hundred universities' goals are shared by some universities in the medium and peripheral cohorts (e.g. developing inventiveness, integrating into the world labor market) the reverse occurs much more seldom: only three goals out of nine of the medium and peripheral groups occurred among the missions of some of the top universities considered (e.g. developing leadership, inculcating social responsibility, preserving native cultural and national foundations - the last EG being declared by non-Anglophone universities); (c) most of the repetitive goals of the medium and peripheral universities were not traced across the top cohort at all (e.g. cultivating ethics and morality, developing individual abilities, integrating into the national job market).

Analysis of values declared in the universities missions shows that their distinction is underpinned by the national affiliation rather than the rank of a university. Thus, fundamental nature of higher education is proclaimed by several universities of Russia and Anglophone countries irrespective of their ranks, whereas not detected in most other national EGs considered; morality is accentuated by medium and peripheral universities, such as the Malaysian Tunku Abdul Rahman University, Indonesian Diponegoro University, Russia's Novosibirsk University and St.- Petersburg University; cultural and scientific values alongside with heritage 
preservation are marked in the missions of Peking University, Hebrew University of Jerusalem and several universities of Russia. Patriotism, concern about the native spiritual core, and preservation of traditions are voiced by Peking University, Hebrew University, St.-Petersburg University of Russia. The values of academic freedom, independent scholarship and university autonomy belong to many, including the universities of the USA, Britain, China, Japan, Brazil, Egypt and others.

\section{Discussion}

It can be deduced from the information in the table that EGs of the top cohort are largely geared to global, pragmatic and individualistic pursuits. The fact that many top hundred universities' goals were shared by some universities in the medium and peripheral cohorts did not per se ensure them an advanced rank. This observation indirectly evidences that there is no unquestionable relationship between a university's missions and its rank. However, the medium and the peripheral groups of universities considered have repeated characteristic goals and thematic dominants of their own unshared by most of the top hundred universities considered. This observation suggests that these goals can be related to their rank because, guiding the university operation, they just do not fit in with the QS ranking scales.

This study shows that the goals of the top hundred universities are more numerous, diverse, better formulated and structured than those of the other groups. Besides, EGs of the top cohort are more measurable and verifiable than some goals in the other cohorts. For instance, excellence and personal success can be checked through faculty and students' academic and research achievements and their national and international acknowledgment by titles and grants awarded, Scopus publications, invitations to international events, reviewing and editing international publication activity, etc. The provision of fundamental education can be attested through the curriculum for a specialism and the syllabi of disciplines taught. Contributing to real-world problem solutions can be proved by the visible and demanded creative products of a university, such as research discoveries, invention patents, prototypes, national or international rewards, expertise activity. Some of the medium and peripheral university groups' goals, like social responsibility, the betterment of all humankind are not so easily measured and verified. Not well elaborated, obscurely described, hardly verifiable, hard to achieve EGs of non-top universities may negatively affect the results of the university and, thus partly account for their ranking.

The analysis reveals that EGs can be universal or locally marked. The former are characteristic of the top group universities on all continents and apart from that occur across the three cohorts of universities; the latter are more typical of universities of the middle and peripheral university groups of Latin America, Middle East, Asia and Russia, whose EGs have more specifics compared to universities of the top cohort.

Universal EGs included such, for example, as preparing personal success, developing leadership qualities, integrating into the world labor market; developing inventiveness, creativity; contributing to bettering native community.

Locally marked EGs encompassed developing individual abilities of students, preserving cultural and national foundations and reproducing cultural identity; cultivating ethics, virtue and morality; addressing problems faced by the nation; integrating into the local national job market. 'Developing individual abilities of students' is not similar to the top cohort's 'developing leadership, inventiveness and creativity', as it is essentially more inclusive and humane for many, than promoting excellence of a few. Especially, as studies show that better meeting the needs of students with diverse abilities increases the overall motivation of other students (Naely, 2018, p.92).

It is noteworthy, that the cultural issue occurs in all the three cohorts' EGs, but is expressed differently: in the top group Oxford University it is worded as "to increase our [Anglo-Saxon - O.B.] cultural, societal and economic impact" (University of Oxford, 2018), whereas in non-Anglo-Saxon universities a cultural goal reads like "transformation of our [French - O.B.] society' (Sorbonne, 2020), "preservation of Jewish cultural, spiritual, and intellectual traditions" (Medina, 2019); "adherence to Chinese cultural heritage and spiritual core" (Min, 2019); "preservation, protection, and promotion of the Russian language, culture, and humanitarian values" (S.-Petersburg university, 2018; Садовничий, 2019), the cultivation of Latvian and culture (Kohler et al., 2009).

Further to this observation, the top cohort ambitious Anglophone EG of impacting the world through cultural, societal, and economic change is definitely not typical of non-top universities. Contrarily, preserving cultural and national foundation goal did not occur in any of the Anglophone universities' missions considered in this study. The evidence above suggests that strategic EGs of universities across the globe do not necessarily coincide with the top Anglophone core values that underpin the QS global university ranking system. Therefore it does not appear incidental that more than half of the top hundred universities are of Anglo-Saxon affiliation (QS World University Rankings Yearbook, 2021). 
Strategic EGs revealed various perspectives and core focus cross-culturally, which tells on universities' policies and performance. Therefore they can be misunderstood and underestimated by university ranking centers. Locally colored specific EGs should not be interpreted as a cause of these universities' less successful performance. In contrast, concern about preservation of national foundations and culturally justified EGs is existentially important for national communities and for humanity and civilization diversity for their further sustainable development. The question is whether this consideration is accepted and taken into account by creators of world university ranking systems when assessing universities.

As it is commonly known, Quacquarelli Symonds, a British company, specializes in analysis of higher education institutions around the world and applies the following metrics (QS Yearbook, 2021):

1. Academic reputation (40\%) measuring sentiment in the academic community about universities by surveying. It collates expert opinions of over 100,000 individuals in the higher education space regarding teaching and research quality at the world's universities. Although the aggregated numerical representativeness of this mark looks impressive, the result highly depends on the knowledge and objectivity of the academics participating, who are appointed by the QS company. Moreover, international academia opinions are represented disproportionately: in the 2008 QS survey $10 \%$ of academic reviews came from the USA, about $9 \%$ from Britain, $4.5 \%$ from Australia, 3.76\% from Canada, 2.5\% from New Zealand, 2.12\% from Singapore, 1.5\% from Hong Kong (about $30 \%$ from Anglophone locales), whereas only 0.99\% from Brazil, 0.93\% from Mexico, 0.68\% from Thailand, $0.65 \%$ from Russia (Huang, 2012). Noteworthily, countries' levels of the QS ranking tested by running the Pearson correlation coefficient and by Spearman rank correlation proved that the higher number of returned questionnaires of a country resulted in higher universities ranking of that country (Huang, 2012), which cannot but question the justness of this ranking system.

2. Employer reputation globally (10\%). University education is a means by which students can receive preparation for international employment market. The orientation of university education on global business demands has twofold consequences. First, it means neglect of fundamental/basic education. Second, universities providing excellent personnel for national or regional needs just do not fit into the QS coordinates by default.

3. Faculty/Student Ratio (20\%). It recognizes that a high number of faculty members per student will reduce the teaching burden on each individual academic.

4. Citations per faculty (20\%). This indicator measures institutional research quality and is not unquestionable either. First, all citations data are sourced from the world's largest Web of Science and Scopus database, the requirements of publication being elaborated by the Anglophone community. Second, it is no secret that quotation policies of journals are not impartial: some require from authors quoting publications in the same journal; others insist on quoting Scopus publications only. So, the process is biasedly guided, that is why its results can doubtedly be regarded as an objective indicator of a university's work quality.

\section{International faculty ratio (5\%).}

6. International student ratio (5\%). The last two criteria are another confirmation of a highly global outlook and demonstrate an ability to attract faculty and students from across the world, which in turn suggests that a university possesses a strong international brand. It provides students with international sympathies and global awareness: soft skills increasingly valuable to employers.

A mere cursory overview of the QS requirements shows that they are obviously geared toward globalization and pragmatic human reproduction for the world labor market. Meanwhile, it is important in what cultural-historical educational system the university operates; how the university sees its higher education mission and strategic goals. These variables cannot but influence the university's activity results. However, the QS system makes no allowances for particular national concepts of education, cultural priorities and interests reflected in universities' educational missions. The QS metrics show that strategic EGs are practically not considered for university rating. Therefore this ranking system would not objectively assess the implementation of such missions. This conclusion is enhanced by the deduction made by the United Kingdom higher education think tank, the Higher Education Policy Institute or HEPI: as Bahram Bekhradnia, the author of the report and HEPI president said, there is evidence that university rankings are one-dimensional, measuring research activity, and there are numerous functions universities fulfill that do not feature in the QS ranking (Malley, 2016). Some scholars openly call university rankings "artificial zero-sum games", because they force a strict hierarchy upon universities and because, they make it realistic for a university to improve its reputation only at the expense of other universities' reputations (Brankovic, 2021). 
It is no coincidence that alternative systems for assessing the performance of universities arise, for instance, Academic Ranking of World Universities by Shanghai University and others. In 2017 the Three University Missions Moscow International University Ranking, briefly known as the Moscow Ranking (MosIUR. The Three University Missions, 2016-2022), was launched as a global ranking of academic universities developed by the Russian Association of Rating Makers with the participation of the international association IREG Observatory on Academic Ranking and Excellence. Alongside with traditional quality of educational and research work, for the first time in the history of global academic rankings, it consistently evaluates the universities' contribution to society (third mission). To compile the rating, only objective criteria approved by international experts are used, whereas reputation polls are excluded. The sources of information for the Moscow ranking are open data from the official websites of universities and national authorities, as well as data from independent international sources, such as the bibliometric data provider Clarivate Analytics, the largest aggregator of online course platforms Class Central; platforms of mass education "Open Education" (Russia) and icourse163.org (China); social networks like Facebook, Twitter, VK, Sina Weibo; Alexa company, one of the world leaders in the field of web analytics; websites of international student scientific contests; scientific awards websites from the IREG List of International Academic Awards. The methodology of the Moscow ranking includes as an important criterion "number of massive open online courses of the university," - i.e. the weighted sum of courses hosted on various platforms, like the aggregator Class Central, as well as the platforms of Open Education and icourse163.org. Each platform is assigned a weight based on the total number of listeners.

\section{Conclusion}

The QS university ranking system demonstrates that strategic educational goals are practically ignored in university ranking. The results of the research can be interpreted twofold: certain goals and values seem to be markers of top universities and tend to be partially shared by other university cohorts, however, without tangible effect on their performance within the QS requirements and without gaining them a top rank. This proves that there is no direct relationship between EGs and university ranks. On the other hand, the studied medium and peripheral universities' goals are more locally marked, less involved with the globalized agenda and, consequently, not much shared by the top group of universities. The fact that the medium and peripheral cohorts of universities considered have repeated characteristic educational goals of their own, suggests that these goals can be related to their rank because they signal specificities ignored by the existing ranking scales and partially account for failure to meet the QS standards. In other words, a causal relationship between universities' EGs and their ranks cannot be completely ruled out. So, there can be no unequivocally positive answer to the question in the title of this study.

Since university ranking is related not only to the prestige of a university but also to funding allocated by governments to the best acknowledged universities, university ranking objectivity takes on a very tangible perspective. In this connection this paper's significance is in making salient necessity for contextual evaluation of universities' efficacy, in drawing attention to relationship between university rank and its strategic educational goals. Anyway, further elaboration and diversification of university ranking criteria are required in the future, as objective assessment of a university's operation is hardly possible outside the socio-cultural context and without considering university EGs.

Restrictions of this research include lack of randomized pick of universities within the cohorts. Besides, it is desirable to test the validity and reliability of this research results over time, content, and across researchers.

\section{Conflict of interests}

The author declares no conflict of interest.

\section{References}

Alexandria University. Faculty of education. (2021). Mission, vision and values. Retrieved from https://edu.alexu.edu.eg/index.php/en/about/mission-vision-and-values

Alexandria University. OER World Map. Retrieved from https://oerworldmap.org/resource/urn:uuid:a3e0db9a-fe6a-497e-9e49-552d4d80bfc9

Ambrose, S., Bridges, M., DiPietro, M., Lovett, M., \& Norman, M. (2010). How learning works: Seven research-based principles for smart teaching. San Francisco, CA, USA: John Wiley \& Sons, Inc.

Anderman, E., \& Patrick, H. (2012). Achievement goal theory, conceptualization of ability/intelligence, and classroom climate. In S. L. Christenson, A. L. Reschly, \& C. Wylie (Eds.), The handbook of research on student engagement (pp.173-191). Springer Science. https://doi.org/10.1007/978-1-4614-2018-7 
Auerbach, C. F., \& Silverstein, L. B. (2003). Qualitative data: An introduction to coding and analysis. N.Y.: New York University Press.

Australian National University. (2018, August). A Vision for Excellence in Learning and Teaching at the Australian National University. Retrieved from https://www.anu.edu.au/files/resource/Vision\%20for\%20Excellence\%20in\%20Teaching\%20and\%20Learni ng\%20at\%20ANU_August2018.pd

Bagley, S. S., \& Portnoi, L. M. (2014). Setting the stage: Global competition in higher education. New Directions for Higher Education, 168, 5-11. https://doi.org/10.1002/he.20109

Bok, D. (2003). Universities in the Marketplace: The Commercialization of Higher Education. New Jersey: Princeton University Press.

Brankovic, J. (2021, March 22). The Absurdity of University Rankings. LSE Impact. Retrieved from https://blogs.lse.ac.uk/impactofsocialsciences/2021/03/22/the-absurdity-of-university-rankings/

Cervone, B., \& Cushman, K. (2012). Teachers at work: Six exemplars of everyday work. The Students at the Centre Series. Retrieved from https://jfforg-prod-new.s3.amazonaws.com/media/documents/Exec_CervoneCushman_032312.pdf

Chan, R., Brown, G. T., \& Ludlow, L. (2014). What is the purpose of higher education? A comparison of institutional and student perspectives on the goals and purposes of completing a bachelor's degree in the 21st century. Retrieved from https://www.dal.ca/content/dam/dalhousie/pdf/clt/Events/Chan_Brown_Ludlow(2014).pdf

Chulalongkorn University (Thailand). Main Mission. Retrieved from https://www.chula.ac.th/en/about/overview/main-mission/

Dietz, B., van Knippenberg, D., Hirst, G., \& Restubog, S. L. D. (2015). Outperforming whom? A multilevel study of performance-prove goal orientation, performance, and the moderating role of shared team identification. Journal of Applied Psychology, 100(6), 1811. https://doi.org/10.1037/a0038888

Diponegoro University School of Postgraduate Studies (Indonesia). Profile. Retrieved from http://pasca.undip.ac.id/v2/vision-mission-and-goals/

Higher School of Economics University (Russia). Statement of Values. Retrieved from https://www.hse.ru/en/info/statement

Huang, M.-H. (2012). Opening the black box of QS World University Rankings. Research Evaluation, 21(1), 71-78. https://doi.org/10.1093/reseval/rvr003

Implications. Journal of Education and Development, 1(1), 58-71. https://doi.org/10.20849/jed.v1i1.253

Indian Institute of Technology Bombay. Vision and Mission. Retrieved from http://www.et.iitb.ac.in/Vision_Mission.html

Kauppinen, I. (2014). Different meanings of 'knowledge as commodity' in the context of higher education. Critical Sociology, 40(3), 393-409. https://doi.org/10.1177/0896920512471218

King Saud bin Abdulaziz University. Development and quality management affairs strategy. Retrieved from https://www.ksau-hs.edu.sa/Dqm/AboutUs/OurStrategy

King Saud bin Abdulaziz University. KSAU-HS Mission, Vision and Objectives. Retrieved from https://www.ksau-hs.edu.sa/Dqm/KSAU-HS/Mission-Vision

Kohler, J., Kristensen B., Machado dos Santos, S., Valdimarsson, J. O., \& Davies, J. (2009). University of Latvia at Riga evaluation report. European University Association. Retrieved from https://www.iep-qaa.org/downloads/publications/university\%20of\%20latvia\%20final\%20report.pdf

Lemoine, P. A., Jenkins, W. M., \& Richardson, M. D. (2017). Global Higher Education: Development and

Locke, E. A., \& Latham, G. P. (1991). A theory of goal setting and task performance. Academy of Management Review. $\quad$ Retrieved from https://www.researchgate.net/publication/232501090_A_Theory_of_Goal_Setting_Task_Performance

Malley, B. O. (2016, 15 December). Global university rankings data are flawed - HEPI University World News. The Global Window on Higher Education. Retrieved from https://www.universityworldnews.com/post.php?story=20161215001420225 
Medina, B. (2019, September). Hebrew University's contribution to the community. The Hebrew University of Jerusalem. Retrieved from https://en.rector.huji.ac.il/book/universitys-contribution-community

Meredith, L.-A. (2014, February 12). What are the 7 Goals of Education?. The Educator's Room. Retrieved from https://theeducatorsroom.com/7-goals-education/

Min, J. T. R. (2019, June 18). Peking University unveils "Global Excellence Strategy". Peking University. PKU News. Retrieved from https://newsen.pku.edu.cn/news_events/news/focus/8660.htm

MosIUR. The Three University Missions. (2016-2022). Moscow International University Ranking "The Three University Missions (Московский Международный рейтинг вузов)". Retrieved from https://mosiur.org/methods/methodology/

Naely, M. (2018). The Effects of Multimedia Technology on Electrical Engineering Students' Reading Achievement. The Asian ESP Journal, 14(6), 86-94.

Nicholls, J. G., Cheung, P. C., Lauer, J., \& Patashnick, M. (1989). Individual differences in academic motivation: Perceived ability, goals, beliefs, and values. Learning and Individual Differences, 1(1), 63-84.

Novosibirsk State Pedagogical University. Education, Science and Innovations. NSPU's vision of its future, p. 5. Retrieved from https://nspu.ru/sveden/mezhdunarodnoe-sotrudnichestvo/EDUCATION,\%20SCIENCE\%20AND\%20INNOVAT ION.pdf

Peterson, A., Dumont, H., Lafuente, M., \& Law, N. (2018, April). Understanding innovative pedagogies: Key themes to analyze new approaches to teaching and learning. OECD Education Working Paper No. 172, 5. Retrieved from https://www.oecd-ilibrary.org/education/oecd-education-working-papers_19939019?page=5

QS World University Rankings Yearbook. (2021). QS Quacquarelli Symonds limited, London, UK. Retrieved from https://www.qs.com/portfolio-items/qs-world-university-rankings-yearbook-2021/

Russian State University for the Humanities. RUSVUZ Educational Center. State University of Humanitarian Sciences. $\quad$ Retrieved from https://www.rusvuz.com/economics-universities/state-university-of-humanitarian-sciences-moscow/

Russian State University for the Humanities. The mission of RSUH as a leading Russian academic and educational center in the field of liberal arts, social and information sciences. Retrieved from https://www.rsuh.ru/en/about-us/about-our-university/

Schwarz, S. (2003). The higher purpose. Times Higher Education. The World University Rankings. Retrieved from https://www.timeshighereducation.com/comment/columnists/the-higher-purpose/176727.article

Shiraz University of Medical Sciences. Education missions and values. Retrieved from http://gsia.sums.ac.ir/en/page/18650/Vision--Mission---Core-Values

Sorbonne University. (2020). Three questions for Jean Chambaz, President of Sorbonne University. Retrieved from https://www.sorbonne-universite.fr/en/foundation/welcome-future/goals

Stanford University. Institutional Research and Decision Support. Mission and goals. Retrieved from https://irds.stanford.edu/assessment/mission-goals

Stensaker, B., Lee, J. J., Rhoades, G., Ghosh, S., Castiello-Gutiérrez, S., Vance, H., ... O’Toole, L. (2018). Stratified university strategies: The shaping of institutional legitimacy in a global perspective. The Journal of Higher Education, 14, 1-24. https://doi.org/10.1080/00221546.2018.1513306

TARC Tunku Abdul Rahman University College. Philosophy, mission and vision. Retrieved from https://www.tarc.edu.my/tarc-uc/philosophy-mission-vision/

The University of Tokyo Charter. (2003). Academic pursuits. Retrieved from https://www.u-tokyo.ac.jp/en/about/charter.html

Universitas Diponegoro, Indonesia. Vision and Mission. Retrieved from https://www.undip.ac.id/language/en/vision-and-mission

Universiti Tunku Abdul Rahman (Malaysia). Introduction. Retrieved from https://utar.edu.my/Introduction.php

University of Brasilia. South-South Galaxy. Retrieved from https://my.southsouth-galaxy.org/en/data/universidade-de-bras\%C3\%ADlia-unb

University of Oxford. (2018). Strategic Plan 2018-23. Retrieved from 
https://www.ox.ac.uk/sites/files/oxford/field/field_document/Strategic\%20Plan\%202018-23.pdf

University of Toronto. Mission. Retrieved from https://www.utoronto.ca/about-u-of-t/mission

Voronezh State University (Russia). Mission. Retrieved from https://www.vsu.ru/english/about/mission.html

Waller, R. E., Lemoine, P. A., Mense, E. G., \& Richardson, M. D. (2020, April). Building capacity for quality assurance in global higher education. Journal of Education and Development, 4(1), 37-42. https://doi.org/10.20849/jed.v4i1.718

Wawrzinek, D., Ellert, G., \& Germelmann, C. Ch. (2017). What's the Purpose of Higher Education? Proposing Meso-Level Operationalizable Superordinate Strategic Goals for Higher Education. Developing the Higher Education Strategy Model and Metrics. Journal of Education and Development, 1(1), 12-23.

Бондаревская, Е. В. (2010). Модернизация педагогического образования в инновационном пространстве федерального университета [Bondarevskaya, Ye.V. Modernization of pedagogical education in the innovative space of the federal university]. Известия Волгоградского государственного педагогического университета, $1(9), \quad 43-51 . \quad$ Retrieved from https://cyberleninka.ru/article/n/modernizatsiya-pedagogicheskogo-obrazovaniya-v-innovatsionnom-prostra nstve-federalnogo-universiteta

Бондаревская, Е. В. (2013). Методология проектирования инновационного пространства педагогического образования в федеральном университете [Bondarevskaya, Ye.V. Innovative Space Designing Methodology for Pedagogical Education at a Federal University]. Известия Волгоградского государственного педагогического университета, 7(82), 4-13. Retrieved from https://www.elibrary.ru/contents.asp?id=33935970

Садовничий, В. А. (2019). Евразийская миссия университетов. / Ред. кол.: В. А. Садовничий и др. Москва: МАКС Пресс, 2019. - 440c. [Sadovnichy V., А. Eurasian Universities Mission]. Retrieved from http://www.eau-msu.ru/files/2019_3_missions.pdf

Санкт-Петербургский государственный университет. (2018). Проект Программы развития федерального государственного бюджетного образовательного учреждения высшего профессионального образования "Санкт-Петербургский государственный университет" до 2030 года. Пояснительная записка. [Draft Program for the development of the federal state budgetary educational institution of higher professional education "St. Petersburg State University" until 2030. Explanatory note]. Retrieved from https://spbu.ru/sites/default/files/20200831_povestka_us_spbu_material_2.pdf

\section{Copyrights}

Copyright for this article is retained by the author(s), with first publication rights granted to the journal.

This is an open-access article distributed under the terms and conditions of the Creative Commons Attribution license (http://creativecommons.org/licenses/by/4.0/). 